\title{
250. rocznica powstania budżetu w Polsce?
}

\section{0th anniversary of budget in Poland?}

Streszczenie. Informacja o tym, że pierwszy budżet państwa stworzono w Polsce już w 1768 r., jest rozpowszechniona i znaleźć ją można nawet w podręcznikach. Paradoksalnie jednak brakuje badań nad tym pierwszym polskim budżetem. Przypadająca 250. rocznica uchwalenia tego aktu skłania do analizy zarówno jego treści, jak i praktyki wykonania. Obie bowiem budzą wątpliwości, czy rzeczywiście mamy do czynienia z budżetem. Akt ten nigdy nie wszedł w życie i miał tak liczne uchybienia, że dotychczasowe sądy o nim należy zrewidować.

Słowa kluczowe: budżet państwa; historia budżetu; konstytucja sejmowa z 1768 r.; Rzeczpospolita Obojga Narodów.

\begin{abstract}
The fact that the first government budget in Poland was already created in 1768 is now widespread and can be found even in textbooks. Paradoxically, there is no comprehensive research on this first Polish government budget. 2018 will mark the 250th anniversary of its adoption, which provides a great opportunity to analyze the budget's content and implementation. Both are raising doubts whether or not we are really dealing with a budget. As the act never came into
\end{abstract}


force and had numerous deficiencies, the opinions issued on it so far need to be revised.

Keywords: government budget; history of budget; act of parliament (1768); Polish-Lithuanian Commonwealth.

\section{Problem}

Powszechnie przyjmowana teza mówi, iż w Polsce już w 1768 r. pojawił się budżet państwa ${ }^{1}$. O niezwykle wczesnym pojawieniu się instytucji budżetu informują nawet podręczniki akademickie, zarówno historii prawa $^{2}$, jak i finansów oraz prawa finansowego ${ }^{3}$, więc nie można się dziwić, że sformułowania takie trafiają potem nawet do współczesnego orzecznictwa sądowego ${ }^{4}$. Tego pierwszeństwa polskich rozwiązań budżetowych, od których starsze na świecie miały by być tylko brytyjskie, nie dostrzega jednak nauka i piśmiennictwo w innych krajach. Taki stan rzeczy Natalia Gajl tłumaczyła brakiem systematyczności w rodzimym budżetowaniu oraz względami językowymi ${ }^{5}$. Czy to te względy stoją za tym, że odmawia się nam zasługi stworzenia pierwszego w kontynentalnej Europie budżetu, czy też może jednak nasze wyobrażenia o osiągnięciach antenatów są nieco na wyrost? Mija 250 lat (1768-2018) od uchwalenia przez sejm aktu, który dał podstawę do wysuwania tez o polskim przodownictwie, rocznica stanowi więc dobrą okazję do przeprowadzenia krytycznej

1 Autor próbował już wcześniej polemizować z tym twierdzeniem w pracy: Poczq̨tki instytucji budżetu państwa w Polsce, Poznań 2014, s. 86-92.

2 J. Bardach, B. Leśnodorski, M. Pietrzak, Historia ustroju i prawa polskiego, Warszawa 2009, s. 320-321; T. Maciejewski, Historia ustroju i prawa sq̨owego Polski, Warszawa 2011, s. 69-70.

3 E. Chojna-Duch, Podstawy finansów publicznych i prawa finansowego, Warszawa 2012, s. 124-125; A. Drwiłło (red.), Podstawy finansów i prawa finansowego, Warszawa 2014, s. 321; B. Brzeziński, A. Olesińska (red.), Prawo finansów publicznych, Toruń 2017, s. 86.

4 Uchwała składu siedmiu sędziów NSA z dnia 12 listopada 2001 r., sygn. FPS 11/2001, Centralna Baza Orzeczeń Sądów Administracyjnych (CBOSA).

5 N. Gajl, Gospodarka budżetowa w świetle prawa porównawczego, Warszawa 1993, s. 30 . 
analizy mającej na celu znalezienie odpowiedzi na pytanie, czy to, co powstało w 1768 r., rzeczywiście jest pierwszym polskim budżetem państwa?

Podjęcie tego typu rozważań wydaje się jak najbardziej zasadne,

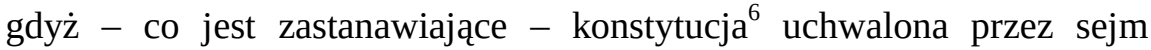
w 1768 r., która traktowana jest jako ów pierwszy polski budżet, nie doczekała się dotąd właściwego naukowego opracowania. Zainteresowanie tą regulacją przyszło po niemal stu latach od jej przyjęcia, gdy zaczęło ukazywać się w częściach opracowanie Henryka Rossmana ${ }^{7}$. Jednak ta niedokończona praca już przez współczesnych badaczy została oceniona niezwykle krytycznie - Adolf Pawiński postanowił nie odnosić się do niej, tłumacząc to tym, że w kwestiach początków budżetu jest ona pozbawiona „wszelkiej podstawy naukowej”" . Tadeusz Korzon w swej monumentalnej pracy dotyczącej dziejów społeczno-gospodarczych czasów stanisławowskich również skrytykował ustalenia Rossmana i nawet się owym budżetem nie zajął, twierdząc, że może on mieć „wartość tylko literacką”, ale nawet w takim przypadku nie dostrzegając w nim zalet „godnych studyowania”9 . Później kwestia tego aktu bywała oczywiście wspominana w pracach historyków czy skarbowców, ale na jej osobne ujęcie czekać było trzeba kolejne sto lat. Ukazała się wówczas jedyna dotąd praca, w której akt z 1768 r. potraktowano jako odrębne zagadnienie. Stało się to w okolicznościowym artykule Jana Bielaka, opublikowanym na dwusetną rocznicę jego uchwalenia ${ }^{10}$. Ta drobna praca o charakterze popularnym omawia na podstawie wybranej literatury dzieje polskiej skarbowości. Autor nie dał się poznać z jakichkolwiek badań czy innych publikacji, a brak historycznych kompetencji zdradzają już pierwsze zdania, w których twierdzi, iż ustawa budżetowa otrzymała moc obowiązującą

Konstytucją nazywano wówczas każdą uchwałę sejmową.

H. Rossman, Rys historyczny budżetu w Polsce, „Ekonomista” 1865, kwartał 4, s. 1323, 81-96; 1866, s. 1-21; 1868, II półrocze, s. 217-229.

8 A. Pawiński, Skarbowość Polski i jej dzieje za Stefana Batorego, Warszawa 1881, s. 304, przypis 1 .

9 T. Korzon, Wewnętrzne dzieje Polski za Stanisława Augusta (1764-1794), t. III, Warszawa-Kraków 1897, s. 140, przypis.

10 J. Bielak, Ogólna charakterystyka ustawy budżetowej z roku 1768, „Finanse” 1968, nr 1, s. 14-23. 
poprzez wpisanie jej do Volumina Legum ${ }^{11}$. Pisząc o konstytucji z 1768 r., nie tylko nie miał pojęcia o dawnym prawie, ale nawet nie zadał sobie trudu zajrzenia na stronę tytułową tegoż Volumina Legum, z której można wyczytać, iż tom VII tego zbioru, w którym zawarto rzeczoną konstytucję, wydali oo. pijarzy dopiero w 1782 r. Opinie wyrażone przez J. Bielaka rozpoczynają festiwal dalszych błędów, które przez kolejne lata zostały rozpowszechnione przez autorów korzystających ze wspomnianego tekstu, gdyż artykuł ten pozostaje do dziś jedynym osobnym opracowaniem aktu z $1768 \mathrm{r}$.

Dzieje się tak również z tego powodu, że wprawdzie w wielu kolejnych publikacjach można znaleźć rozważania dotyczące początków budżetu, to jednak ich autorzy nie pokusili się na własne, krytyczne zbadanie konstytucji sejmowej z 1768 r. Ustalenia Bielaka i Rossmana wciąż są powielane, a brakuje prób zweryfikowania i skorygowania opinii zawartych w obu tych pracach. Być może to skutek znanej wśród badaczy niechęci do zajmowania się problemami już wcześniej naukowo opracowanymi, gdyż nawet Marian Drozdowski, autor kilku prac o początkach budżetowania $\mathrm{w}$ przedrozbiorowej Rzeczpospolitej, nie wyszedł poza narzucony schemat. Słusznym wydaje się tu przywołanie spostrzeżenia Emanuela Rostworowskiego, który pisał, iż „w nauce historycznej błąd miewa uporczywe życie; raz zapuściwszy korzenie, może w postaci pseudofaktu owocować przez wiele pokoleń” ${ }^{12}$. Przykład pierwszego polskiego budżetu stanowić może doskonałą ilustrację tego stwierdzenia.

\section{Na drodze do konstytucji z 1768 r.}

Dostrzeżono, że w dawnej Rzeczpospolitej istniały niezbędne warunki do powstania budżetu. Majątek państwowy został oddzielny od majątku panującego władcy, władza królewska zaś została ograniczona na rzecz ciała przedstawicielskiego (sejmu), który decydował zarówno o dochodach, jak i o wydatkach publicznych. Jednak uwarunkowania takie zaistniały już

\footnotetext{
Tamże, s. 14.

12 E. Rostworowski, Legendy i fakty XVIII w., Warszawa 1963, s. 5.
} 
w wieku XVI, a na zalążki kształtowania się budżetu trzeba było czekać jeszcze niemal dwa stulecia.

Za pierwszą jaskółkę zmian uznaje się regulację, którą w 1717 r. przyjął Sejm Niemy, zwołany, by zaprowadzić spokój w targanej konfliktami Rzeczpospolitej. W sposób bezprecedensowy posłowie milcząco zaaprobowali przedstawione im propozycje reform. W literaturze z pojęciem „budżet” możemy spotkać się już właśnie w odniesieniu do ustawodawstwa Sejmu Niemego, jednak określenie to w stosunku do ustalonego tam etatu wojska zwanego „punktualną płacą” zdaje się być poważnym nadużyciem. Już przedwojenni autorzy mieli tu problem z nazewnictwem, bowiem Michał Nycz śmiało używał określenia „budżet” lub „,budżet wojskowy”, gdy natomiast Roman Rybarski stosował sformułowanie „stały etat wojskowy” ${ }^{\text {13 }}$. Późniejsi badacze też nie doszli do spójnej oceny, gdyż dla M. Drozdowskiego ta regulacja była prototypem budżetu, a z kolei N. Gajl widziała w niej raczej formę zbliżoną do gospodarki funduszowej ${ }^{14}$. Wydaje się, że rację przyznać trzeba tym, którzy unikają określeń wiążących „stała płacę” z budżetem, choćby tylko z tego względu, że reforma miała znamię trwałości, eliminując potrzebę jakichkolwiek zmian w skarbowości i w ogóle funkcjonowania sejmu. Tym samym znikał tak istotny dla powstania budżetu element, jakim było decydowanie przez parlament o wydatkach i dochodach. Akt ten nie wynikał z jakiegoś organicznego rozwoju form budżetowych, ale był skutkiem potrzeby chwili. Uniezależniał utrzymanie wojska od niepewnych efektów działania ówczesnego sejmu i sejmików, których dysfunkcja była już wówczas doskonale widoczna. Ze współczesnego punktu widzenia akt z 1717 r. należy też ocenić bardziej jako kuriozalny niż nowatorski, gdyż zamienił niewielką armię Rzeczpospolitej w grono poborców podatkowych, którzy

13 M. Nycz, Geneza reform skarbowych Sejmu Niemego. Studium z dziejów skarbowowojskowych z lat 1797-1717, Poznań 1938, s. 212-214; R. Rybarski, Nauka skarbowości, Warszawa 2015, s. 65. Kilka lat temu Tomasz Ciesielski bardzo nieszczęśliwie odniósł pojęcie budżetu do okresu 1717-1763, zob. T. Ciesielski, Armia koronna w czasach Augusta III, Warszawa 2009.

14 M. Drozdowski, Działalność budżetowa sejmu Rzeczpospolitej w czasach saskich, „Roczniki Dziejów Społecznych i Gospodarczych” 1977, t. 38, s. 128-135; N. Gajl, Budżet a skarb państwa, Warszawa 1974, s. 65. 
egzekwowali należności publiczne, a następnie je dosłownie przejadali, albowiem te przeznaczone były na ich utrzymanie.

Ów stworzony w 1717 r. system utrzymania wojska funkcjonował prawie 50 lat, gdyż zmodyfikowany został dopiero przez sejm w 1766 r. ${ }^{15}$ Działo się to już w nowych warunkach - czasy Stanisława Augusta przywróciły sprawność sejmowi, który odtąd nie był już zrywany. Reformy z początków panowania tego władcy objęły również wojskowość i skarbowość. Powołane wówczas komisje skarbowe mogły zacząć tworzyć nowoczesną administrację zajmującą się poborem podatków, a wojsko mogło zająć się tym, do czego było powołane. W takich okolicznościach w 1768 r. sejm repninowski uchwalił konstytucję „Ostrzeżenie percepty y expensy, wszystkich intrat Skarbow oboyga narodow, podług niżej opisanych tabell”16, która - jak określił to R. Rybarski - jest „in nuce dzisiejszą ustawą skarbową". Natomiast wspomniane tabele miały być odpowiednikiem cyfrowej części współczesnego budżetu ${ }^{17}$. Rybarski jako doskonały skarbowiec patrzył już na akt z 1768 r. tak, jak robimy to współcześnie, odróżniając budżet od ustawy budżetowej, która ów budżet zawiera $^{18}$. Konstytucję z 1768 r. określa się więc jako pierwszą ustawę budżetową, która tworzyła pierwszy budżet państwa i jako taka była przełomem w skarbowości Rzeczypospolitej.

\section{Kształt konstytucji z 1768 r.}

Regulacje z 1768 r. nie wzięły się ex nihilo, a były efektem ewolucji, jakie przeszedł system finansowania wojska stworzony w 1717 r. Do funkcjonującej dotychczas i tylko zmodyfikowanej w 1766 r. regulacji dotyczącej utrzymania wojska dodano listę wydatków o charakterze cywilnym, co

\footnotetext{
Volumina Legum, t. VII, f. 455-459, 528-532.

Volumina Legum, t. VII, f. 636-643.

R. Rybarski, Skarbowość Polski w dobie rozbiorów, Kraków 1937, s. 39.

A. Drwiłło (red.), Podstawy finansów..., s. 324; zob. też C. Kosikowski, Budżet państwa jako kategoria historyczna, ekonomiczna i prawna, [w:] E. Ruśkowski (red.), System prawa finansowego, T. 2., Prawo finansowe sektora finansów publicznych, Warszawa 2010, s. 201-203; P.M. Gaudemet, J. Molinier, Finanse publiczne, Warszawa 2000, s. $165-166$.
} 
stanowi o odmienności całego rozwiązania. Jednak pod względem technicznym wyglądało to odwrotnie, tj. regulację sprzed dwóch lat potwierdzono i po prostu wciągnięto do nowego aktu. Czy jednak ten zabieg wystarcza, by uznać, że w 1766 r. budżetu jeszcze nie było, a w 1768 r. już był?

Przepisy konstytucji stanowiły polecenie dla komisji skarbowych do dokonywania wypłat, tworząc podstawę prawną dla zamieszczonych poniżej tabel. Te odrębne tabele, których stworzono aż osiem, były zestawieniem rachunkowym dochodów i wydatków. Pierwsza tabela zawierała preliminowane wpływy coroczne, a druga wpływy, które miały ustać po wprowadzeniu nowego podatku czopowego. W trzeciej określono coroczne wydatki zwyczajne, natomiast wydatki nadzwyczajne opisano w tabeli czwartej. Te cztery tabele zawierały wielkości zapisane dla skarbu koronnego, gdyż osobno potraktowano drugą część Rzeczpospolitej, czyli Wielkie Księstwo Litewskie, dla którego analogicznie stworzono następne cztery tabele.

Ponieważ same podatki miały własną podstawę prawną, dlatego też w konstytucji nie zapisano upoważnienia do ich ściągania ${ }^{19}$. W dotychczasowych analizach nie zauważano jednak, że odrębną podstawę prawną posiadały również poszczególne pozycje wydatków. Część z nich wyznaczył ten sam sejm w osobnych konstytucjach i takie same kwoty zostały następnie wpisane do tabel ${ }^{20}$. W tabelach umieszczono też wypłaty, których przedmiot ustanowiono $\mathrm{w}$ latach wcześniejszych, choćby koszty funkcjonowania samych komisji skarbowych, oznaczone w konstytucjach z 1764 r. je powołujących ${ }^{21}$. Oznaczało to, że regulacja z 1768 r. była swego rodzaju podsumowaniem - zbierała w jednym akcie wypłaty, które i tak miały własną podstawę prawną.

Oceniając charakter konstytucji z 1768 r., należy więc uwypuklić, że poszczególne pozycje wydatków zwyczajnych i nadzwyczajnych były tylko powtórzeniem zobowiązań wynikających z wcześniej uchwalonych praw. Tylko nieliczne z nich nie miały odrębnej podstawy ustawowej,

\footnotetext{
19 R. Rybarski, Skarbowość..., s. 39.

20 Konstytucje tegoż samego sejmu, określające różne przedmioty wydatków umieszone w tabelach, zamieszczone są dalej, zob. Volumina Legum, t. VII, f. 643-665.

21 Volumina Legum, t. VII, f. 32-33, 159.
} 
takie jak koszty poselstw czy wydatki na cele nadzwyczajne. I właściwie tylko oznaczenie kwot na wydatki nieprzewidziane można uznać za istotną i potrzebą nowość, bo stworzono prawną możliwość dokonywania wydatków w sytuacjach nadzwyczajnych.

Z tego wszystkiego jednak wynika, iż nie tylko dochody, ale też wydatki zasadniczo wynikały z odrębnych przepisów, i fakt uchwalenia nowej konstytucji, w której wszystko podsumowano, nie zmieniał sytuacji faktycznej konieczności dokonania danych wypłat. W dodatku zakładano optymistycznie, że pełne pokrycie wydatków przyniesie uchwalenie nowych podatków, do czego w rzeczywistości nie doszło. Możemy więc określić, że realizacja „budżetu” była zastrzeżona pod warunkiem, który się nie spełnił. Zastosowany podział na wydatki zwyczajne i nadzwyczajne (ordynaryjne i extraordynaryjne) jest ciekawy, ale trudno uznać za osiągnięcie, bo wynikał po prostu z założenia o wieloletniej mocy obowiązywania przyjętej regulacji. Był to właściwie podział na wydatki stałe (coroczne) i takie, które po zaspokojeniu miały zniknąć, a więc jednorazowe.

\section{Konstytucja a zasady budżetowe}

W XVIII w. nie istniało jeszcze żadne fachowe określenie tego, czym jest lub powinien być budżet. Dlatego przykładanie dziś do rozważań historycznych jakiejkolwiek późniejszej definicji legalnej, niezależnie od tego z jakiego okresu i systemu prawnego wziętej, nie ma żadnego uzasadnienia. Zresztą budżet państwa, stanowiąc kategorię prawną, ekonomiczną i historyczną ${ }^{22}$, nie doczekał się do dziś jednej, ustalonej definicji. Stąd trudno znaleźć wskaźnik, dzięki któremu można by właściwie ocenić polskie rozwiązania z 1768 r. Jeśli by - najogólniej przyjmując - przez budżet rozumieć plan dochodów i wydatków państwa zatwierdzonych na czas przyszły, ale też akt, w którym ten plan się zawiera, to tak szeroko zakreślona definicja pozwala uznać, że nasz rodzimy akt z 1768 r. spełnia te wymagania, więc dzieło sejmu z 1768 r. obejmuje budżet i ustawę bu-

22 Zob. C. Kosikowski, Budżet państwa..., s. 179-230. 
dżetową. Gdyby jednak spróbować posunąć się dalej i postawić dalsze wymogi, sprawa nie jest już tak oczywista.

Wraz z rozwojem instytucji budżetu nauka sformułowała zasady budżetowe, które są postulatami względem charakteru owego planu, lub jak chcą inni - powinny stanowić trwałe jego właściwości ${ }^{23}$. Wprawdzie nie istnieje jeden ich katalog, jednak zasady powszechności (zupełności), jedności materialnej i formalnej oraz szczegółowości są uważane za podstawowe, klasyczne ${ }^{24}$. Do tego zbioru dodaje się często jeszcze zasadę roczności, przejrzystości, jawności i równowagi.

Dziś już nie do obrony jest pogląd, iż nieprzestrzeganie zasad budżetowych powoduje, że budżet nie odpowiada swej definicji ${ }^{25}$, gdyż zasady istnieją niezależnie od stopnia ich zastosowania w praktyce ${ }^{26}$, jednak warto pokusić się o konfrontację aktu z 1768 r. z zasadami budżetowymi. Choć przykładanie do niego współczesnej miary jest ryzykowne i może być uważane za działanie ahistoryczne, to jednak postępują tak poszczególni autorzy, udowadniając, iż konstytucja z 1768 r. była podobna budżetom współczesnym ${ }^{27}$. Jest to jednak raczej przykład myślenia życzeniowego, udowadniającego z góry przyjętą tezę.

Takie przekonania widać już w przypadku zasady jedności formalnej, bo twierdzenie, że akt z 1768 r. obejmował wszystkie dziedziny działalności państwowej ${ }^{28}$ nie znajduje pokrycia w rzeczywistości. Zakres działań

23 Zob. A. Borodo, Budżet państwa a zasady budżetowe, [w:] Nauka finansów publicznych i prawa finansowego w Polsce. Dorobek i kierunki rozwoju. Księga jubileuszowa profesor Alicji Pomorskiej, Lublin 2008, s. 167.

N. Gajl, Gospodarka..., s. 80.

25 Zob. M. Weralski, Budżet państwowy, [w:] M. Weralski (red.), System instytucji prawno-finansowych PRL, t. 2 Instytucje budżetowe, Wrocław 1982, s. 26-27.

26 A. Drwiłło (red.), Podstawy finansów..., s. 328.

27 M. Drozdowski, Poczq̨tki prawa budżetowego w Rzeczypospolitej w czasach Stanisława Augusta, „Czasopismo Prawno-Historyczne”, 1978, t. 30, z. 1, s. 141-142 podkreśla zasady jedności i jawności; N. Gajl, Gospodarka..., s. 28-30 pisała z kolei, że odpowiadał on „w znacznym stopniu zasadzie powszechności” podkreślała jego szczegółowość i dążenie do zachowania równowagi budżetowej.

28 M. Drozdowski, Podstawy finansowe działalności państwowej w Polsce 1764-1793. Działalność budżetowa Sejmu Rzeczypospolitej w czasach panowania Stanisława Augusta Poniatowskiego, Warszawa-Poznań 1975, s. 58; M. Pietrzak, Gospodarka budżetowa w Polsce w latach 1768-1792. Między tradycjq a nowoczesnościq, „Przegląd Sejmowy” 1999, nr 5, s. 12. 
ówczesnego państwa był znacznie węższy niż ma to miejsce dziś, mimo to istniały takie obszary i związane z nimi dochody i wydatki, których w ogóle nie uwzględniono. Przede wszystkim istniał odrębny - jeden dla całej Rzeczypospolitej - skarb królewski. Podział skarbu na publiczny i królewski, który nastąpił w XVI w. ${ }^{29}$, jest równie mocno zmitologizowany, co powstanie budżetu. Oddzielenie majątku władcy od majątku państwowego, które uważane jest za warunek konieczny powstania instytucji budżetu, nie wyglądało w Polsce tak jak w Anglii (Wielkiej Brytanii). U nas skarb monarszy w znacznej mierze zachował charakter publicznoprawny, bo poza utrzymaniem króla i jego dworu opłacano z niego wydatki na szkolnictwo, służbę zagraniczną czy nawet sprawowano mecenat kulturalny ${ }^{30}$. Skarb królewski odróżniał się od skarbu koronnego i litewskiego nie tyle charakterem, co sposobem zarządu, który pozostawiono w rękach królewskich. Król jednak nawet i tu był skrępowany narzuconymi mu przy elekcji warunkami z pactów conventów, w których zobowiązywał się do czynienia konkretnych wydatków ${ }^{31}$. Dochody skarbu królewskiego, na które składały się też daniny o charakterze publicznym (przede wszystkim cła) w 1768 r. sięgały 60\% łącznych dochodów skarbu koronnego i litewskiego ${ }^{32}$. Poza skarbem królewskim istniała też cała niezbadana sfera kosztów funkcjonowania armii. Prócz zachowania wcześniejszych konstytucji dotyczących finansowania wojska (1717, 1766), ponoszone były koszty, których policzyć nie sposób. Jeszcze w epoce Sejmu Wielkiego przy dyskusji o aukcji wojska Józef Pawlikowski pytał retorycznie: „ktoż żywił żołnierzy, kto ich woził, i do tych czas kto ich

29 W. Pałucki, Drogi i bezdroża skarbowości polskiej XVI i pierwszej połowy XVII wieku, Wrocław 1974, s. 22-27.

30 Tamże, s. 276-277, zob. też J. Łojek, Mecenat kulturalny Stanisława Augusta: państwowy czy prywatny? [w:] tenże, Wokół sporów i polemik, Lublin 1991, s. 158-163.

31 Stanisław August zobowiązywał się (w czym podobny był do swych poprzedników) zarówno do ponoszenia konkretnych wydatków, takich jak ufundowanie szkoły rycerskiej, jak i do podejmowania działań, które pociągnąć za sobą mogły wydatki, takich jak odzyskanie utraconych prowincji, Volumina Legum, t. VII, f. 203, 208-209. Dochód skarbu koronnego w roku finansowym 1766/67 wyniósł 6.892.363zł, skarbu litewskiego w 1767 r. M. Drozdowski obliczył na 2.566 .976 zł, natomiast przeciętny roczny dochód skarbu nadwornego w latach 1764-1767 wyniósł 5.662.638 zł (M. Drozdowski, Podstawy..., s. 34, 37; R. Rybarski, Skarbowość..., s. 408). 
żywi, kto ich wozi, ale nietylko żołnierza, ale każdego aresztanta”. Obciążenia takie spadały nie tylko na wieś, bo też miasta i królewszczyzny pisał Pawlikowski - mają „stolowników bez płatnych”33.

Zasada jedności materialnej (czyli przeznaczania całości dochodów na całość wydatków) również nie została wprowadzona, gdyż niektóre dochody powiązano z konkretnymi celami wydatków. Z tekstu samej konstytucji widać, że istniały „podatki na extraordynaryine postanowione expensa”. Wynikiem takiego podejścia było założenie, że po zrealizowaniu celów wydatkowych miało zostać zakończone pobieranie przeznaczonych na nie dochodów.

Zasada powszechności (zupełności), czyli budżetowania brutto, również nie była spełniona, gdyż pozycje dochodów wpisano do tabel w kwotach netto. Oznaczono więc sumy, które miały rzeczywiście wpłynąć do skarbu po dokonaniu wszelkich potrąceń (koszty poboru). Trudno nawet mówić o szacunkach, jak wyglądałby budżet brutto, gdyż problem kosztów działania ówczesnej administracji nie jest do dziś zbadany. Do tego z pewnych dochodów skarbowych dokonywano bezpośrednich płatności, co jest dziś niemożliwe do uchwycenia. Jako przykład niech posłuży regulacja w 1770 r. przez litewską komisję skarbową wydatków, które odejmowano z dochodów płynących do skarbu ze starostwa wielońskiego. Okazało się, że było ono obciążane stałymi wydatkami na procesy, a nawet sumą 600 zł na „potrzeby Kuchenne”34. Tego typu niespodzianek w skarbowości można znaleźć więcej - choćby w 1784 r. na sejmie pytano, dlaczego komisja skarbowa koronna nie podaje w swoich rachunkach płaconego przez kupców „akcydensu szesnastogroszowego”. Magistratura wyjaśniła, że ów podatek pobierany według instruktarza pochodzącego jeszcze od Jana III Sobieskiego nigdy nie był uwzględniany w sprawozdaniach, bo „rozchodzi się na Pensye Officyalistów Celnych”35.

\footnotetext{
[J. Pawlikowski], Myśli polityczne dla Polski, Warszawa 1789, s. 74-75.

34 Litewskie Państwowe Archiwum Historyczne w Wilnie (dalej: LPAH), SA 2770, k. $11 \mathrm{v}-12$.

35 Dyaryusz Seymu Wolnego Ordynaryinego Grodzieńskiego Sześcioniedzielnego Roku Pańskiego MDCCLXXXIV dnia 4 października odprawuiq̨cego się, Warszawa 1785, s. 202-203.
} 
Trudno również mówić o zasadzie roczności. Wprawdzie rachowano oraz określano wpływy i wydatki państwa w okresie rocznym, jednak zakładano, że ten sam „budżet” obowiązywać będzie w kolejnych latach (pierwszą tabelę opisano: „Tabella Intrat corocznych [...] ktora na przyszłe czasy, zostać ma”). Uchwalona konstytucja powinna więc obowiązywać albo do czasu jego uchylenia, albo zastąpienia nową, co w normalnych warunkach mogło mieć miejsce najwcześniej za dwa lata, bo w takim okresie król zobowiązany był do zwołania sejmu. Oczywiście obowiązywać miał nie w całości, gdyż zarówno pewne dochody, jak i wydatki miały ustać (odpowiednie podatki miały być wybierane „pokąd tych wydatków potrzeba będzie”). Stąd zresztą późniejsze przekonanie, że akt z 1768 r. wciąż obowiązuje, podobnie jak kolejne tabele uchwalone w 1775 i 1776 r. W praktyce ustawodawczej Rzeczpospolitej unikano bowiem otwartego znoszenia jakichkolwiek norm, stosując częściej derogację i zastępowanie starej regulacji nową, lub po prostu normy zanikały przez desuetudo ${ }^{36}$. W tym kontekście trzeba też zauważyć, że akt z 1768 r. nie uchylał regulacji z 1717 r., co doskonale obrazują problemy z opłacaniem wojska według konstytucji z 1717 r., gdy po I rozbiorze utracono część ziem, z których wyznaczone były na to dochody. W 1774 r. komisja skarbowa litewska tłumaczyła chorągwi dywizji białoruskiej, która pobierać miała utrzymanie z podatków powiatu orszańskiego, że nie ma z czego jej zapłacić, polecając wojsku samemu wybierać należne mu środki z pozostałej w granicach Rzeczpospolitej części tegoż powiatu ${ }^{37}$.

O pełnym pokryciu wydatków myślano, ale zasada równowagi budżetowej nie była osiągnięta nawet w fazie projektowania. Pod tabelami zapisano bowiem, że brakujące na pokrycie wydatków w Koronie ponad $10 \mathrm{mln}$ zł, a na Litwie ponad $4 \mathrm{mln}$, miały przynieść dopiero nowe podatki. Po zniesieniu części starych obciążeń możliwość realizacji wydatków zawisła od nowego podatku czopowego, który pokrywać miał 60\% rozchodów w Koronie, a na Litwie aż 66\%. Natomiast przy dotychczas ist-

36 H. Grajewski, Granice czasowe mocy obowiqzujqcej norm dawnego prawa polskiego, Łódź 1970, s. 23-28. Zob. też przypis 66.

37 LPAH, SA 2909, k. 258v-259. 
niejących podatkach zapisane wydatki dla Korony mogły być opłacone tylko w 63\%, a na Litwie tylko w 56\%.

Gdy wreszcie spojrzeć na pozostałe zasady budżetowe, to również szczegółowości i przejrzystości trudno jest się dopatrzyć. Brakowało precyzyjnych kryteriów wyszczególniania poszczególnych pozycji - choćby wydatki wojskowe włączone są en bloc z poprzedniej regulacji. Całość dzieła sejmowego jest chaotyczna, a ostatnia pozycja wśród wydatków nadzwyczajnych (,expensy extraordynaryine nieprzeyrzane”) zezwalała na to, by prawie 9\% środków w przypadku skarbu koronnego i ponad 18\% w skarbie litewskim przeznaczonych na wydatki cywilne tworzyło dla komisji skarbowych fundusz, z którego środki mogły być zadysponowane na cele nie przewidziane przez władzę ustawodawczą ${ }^{38}$. Współcześnie zasadę przejrzystości łączy się z zasadą jawności ${ }^{39}$, tu jednak - skoro przejrzystości nie było - należałoby je rozdzielić i stwierdzić, że zasada jawności, oczywiście jak na ówczesne standardy, jest spełniona. Nie wynika to jednak z jakichś szczególnych założeń i nie jest to coś, co by wyróżniało konstytucję z 1768 r., gdyż wobec całego sejmowego dorobku ustawodawczego obowiązywały takie same zasady publicznego ogłaszania. Rzeczpospolita zresztą - w przeciwieństwie do większości ówczesnych państw - nie traktowała sfery swoich finansów jako tajemnicy ${ }^{40}$.

Powyższe uwagi dotyczące zasad budżetowych powodują, że należy oceniać jako niesłuszną opinię, iż akt z 1768 r. spełniał całkowicie wymogi współczesnego budżetu ${ }^{41}$. Było wręcz odwrotnie.

38 Volumina Legum, t. VII, f. 640, 643.

39 R. Mastalski, E. Fojcik-Mastalska (red.), Prawo finansowe, Warszawa 2013, s. 64-65.

40 R. Rybarski, Skarbowość..., s. 47-48.

41 N. Gajl, Gospodarka..., s. 28-29 określiła go jako pierwszy „odpowiadający cechom budżetu, w pełni prawidłowy budżet”; w podręczniku czytamy, że był to „pierwszy polski budżet odpowiadający dzisiejszemu rozumieniu tego aktu”, R. Mastalski, E. Fojcik-Mastalska (red.), Prawo finansowe..., s. 58. 


\section{Realizacja?}

Projekty finansowe, które przygotowała wyłoniona wcześniej subdelegacja, były przedmiotem kilkudniowej dyskusji sejmowej i przyjmowano je sukcesywnie do 3 marca $1768 \mathrm{r}^{42} \mathrm{~W}$ przyjętych regulacjach nie zostało jednak nawet precyzyjnie określone, od kiedy powinny obowiązywać, a przecież poszczególne podatki opłacano wówczas w różnych terminach. Wielkości wpływów opisano na podstawie sum określonych przez kontyngenty bądź na podstawie ostatnich wyników poboru. Taka konstrukcja - w rubryce dochodów tylko szacunki, a w rubryce wydatków poważne rozrzutności i dowolności, połączona z wybrykami konfederacji barskiej spowodowała niemożność wykonania zapisów konstytucji ${ }^{43}$. Konfederaci barscy przejmowali dochody publiczne i tworzyli własną skarbowość ${ }^{44}$, a wojna domowa zakończyła się ostatecznie w 1772 r. pierwszym rozbiorem Rzeczypospolitej. To wszystko - jak się podaje w literaturze - definitywnie przekreśliło możliwość zrealizowania $\mathrm{w}$ pełni strony zarówno dochodowej, jak i wydatkowej.

Cechą, która pozwoli odróżnić budżet od innych planów, jest charakter dyrektywny tego aktu, który stanowi instrukcję postępowania dla władzy państwowej ${ }^{45}$. Skoro akt z 1768 r. nie wszedł w życie ${ }^{46}$, to niektórzy dawniejsi autorzy wyciągali stąd podstawowy argument, że nie jest on budżetem $^{47}$. Późniejsi historycy zdyskredytowali takie opinie, śmiało wyliczając wykonanie znajdujących się w nim zapisów. To wykonanie miało być tylko fragmentaryczne, odnośnie wydatków szacowane na nie więcej

M. Drozdowski, Podstawy..., s. 39-40.

43 Tamże, s. 40-48.

44 Zob. W. Konopczyński, Konfederacja barska. Przebieg, tajemne cele i jawne skutki, T. 2, [Poznań 2017], s. 511-550.

45 I. Czuma, Budżet [w:] Z. Cybichowski (red.), Encyklopedia podręczna prawa publicznego, T. 1, Warszawa s.a., s. 75.

46 Tak np. S. Kutrzeba, Historia ustroju Polski. Korona, Poznań 2001, s. 192; Opinię taką przyjął Z. Stahl, Istota budżetu na tle rozwoju historycznego i współczesnych tendencyj konstytucyjnych, Lwów 1934, s. 25.

47 Zob. przypis 9. 
niż $25 \%{ }^{48}$, ale problem jednak leży gdzie indziej, bo są to wyliczenia wydatków faktycznie poniesionych przez państwo, a nie realizacji jakiegokolwiek planu czy budżetu. Trzeba zauważyć, że - w nawiązaniu do wcześniejszych uwag - obraz dochodów i wydatków państwa nie odbiegałby od zaistniałego, gdyby owej konstytucji z 1768 r. nie uchwalono.

Rzeczywistą planowość i dyrektywność ustawy musiała podważyć praktyka - przyjęty projekt byłby trudny do realizacji nawet w czasach pokojowych. Ale choć niedostatek wpływów nie dawał wielu możliwości na przekroczenie planowanych wydatków, to jednak nawet takie przypadki się zdarzały ${ }^{49}$. Nie było to wcale istotne - nie dość, że na sejmie wybierano nowych komisarzy skarbowych (administrujących dochodami i wydatkami państwa członków komisji skarbowych) przed rozliczeniem ustępujących, to do końca istnienia Rzeczpospolitej nie zdarzyła się odmowa udzielenia im absolutorium, niezależnie od liczby podnoszonych zastrzeżeń ${ }^{50}$. Stąd pokwitowanie działalności komisarzy, którym powinno przypaść wykonywanie konstytucji z 1768 r. $^{51}$, nie może być żadnym wskaźnikiem dla oceny realizacji (lub nie) jej zapisów. Trudno bowiem dostrzec ślady tego, by rzeczywiście przyjęte tabele miały jakiekolwiek znaczenie przy wydatkowaniu pieniędzy. Zbieranie dochodów i dokonywanie wydatków należało wówczas do wspomnianych komisji skarbowych, kolegialnych urzędów, jednego w Koronie, drugiego w Wielkim Księstwie Litewskim. Przy asygnatach wydawanych na wypłaty ze skarbu próżno szukać powoływania się na akt 1768 r., który nigdy nie bywał wspominany ${ }^{52}$. Zamiast tego można spotkać przy dokonywaniu wypłat na rzecz

48 M. Drozdowski, Podstawy..., s. 48-57; M. Pietrzak, Gospodarka budżetowa..., s. 12; Również autor niniejszych słów nie był wolny od tego typu uproszczeń, zob. P.M. Pilarczyk, Poczq̨tki instytucji..., s. 88. Zob. M. Drozdowski, Podstawy..., s. 48, 54-55.

50 Wyjątkiem było dwukrotne odłożenie (z przyczyn politycznych) udzielenia absolutorium komisji litewskiej na sejmach w 1780 i 1782 r.. Ostatecznie jednak brakujące zakwitowania zostały udzielone łącznie w 1784 r., zob. Z. Szcząska, Odpowiedzialność rzq̨du w Polsce w latach 1775-1792, „Czasopismo Prawno-Historyczne”, 1975, t. 27, z. 1, s. 75, 79; Volumina Legum, t. IX, nr XIX, s. 13.

51 Volumina Legum, t. VIII, f. 190-191, 653-654.

52 Ze względu na zniszczenie materiałów archiwalnych komisji koronnej, zamieszczone w tu uwagi bazują na ustaleniach dotyczących komisji litewskiej i jej ksiąg asygnat z lat 1767-1775, LPAH, SA 2846-2848. 
jednostek wojskowych powoływanie się wciąż na regulację z $1717 \mathrm{r}^{53}$ W dodatku wbrew ostrzeżeniom zawartym w akcie z 1768 r. dokonywano swobodnie wielu wydatków, na które nie było żadnego upoważnienia. Wyjaśnienie tego stanu rzeczy znaleźć można w konstytucji następnego sejmu, dotyczącej regulowania długów państwa. Postanowiono tam zaległych wydatków umieszczonych w tabelach z roku 1768 nie uznawać za długi, gdyż te tabele „skutku swego nie wzięły”. Nie dokonywano wydatków, gdy zabrakło wpływów, które „miały być opłacone z podatkow nowo ustanowionych”54. W tym miejscu trzeba przyznać rację dawnym badaczom, upierającym się przy twierdzeniu, że akt z 1768 r. nigdy nie wszedł w życie. Nie został zrealizowany nawet częściowo, bo realizowany nie był.

W świetle podniesionych zastrzeżeń, należałoby zweryfikować opinię, iż akt z 1768 r. rozpoczął planową gospodarkę finansową w Rzeczypospolitej $^{55}$. Nie stanowił on przełomu, a dowolność w wydatkowaniu publicznych pieniędzy trwała w najlepsze także później. W 1776 r. sejm uchwalił regulacje, które stanowiły podstawę gospodarki finansowej przez szereg kolejnych lat. Była to konstytucja „Wydatki Koronne”, do której dołączona została tabela, która miała służyć „za regułę”, zabraniając dokonywania wydatków w niej nie umieszczonych. Podobną tabelę, wraz z nowymi regulacjami podatkowymi, przyjęto dla Wielkiego Księstwa Litewskiego $^{56}$. W 1783 r. Rada Nieustająca sprawująca wówczas centralną władzę wykonawczą prosiła o wyjaśnienie wydatków „nad Tabellę 1776”, a litewska komisja skarbowa tłumaczyła, że istniały „dwa ogulne powody” dokonania takich wydatków, to jest „Sprawiedliwość y Potrzeba z koniecznoscią złączone" ${ }^{57}$. W 1784 r. deputacja sejmowa kontrolująca wydatki komisji litewskiej, znalazła aż 31 pozycji wydatków, które nie

53 Za przykład może służyć ułożony przez litewską komisję skarbową „Dyspartament Podatków Rzplitey na Płacę Woysku WXLittwgo” z 20 czerwca 1769 r. Ustalając wysokość kwot wypłat poszczególnym jednostkom wojskowym, powoływano się wyłącznie na konstytucje z lat 1717, 1764 i 1766 r., LPAH, SA 2847, k. 4v-6.

54 Volumina Legum, t. VIII, f. 166-167.

55 M. Drozdowski, Podstawy..., s. 58.

56 Volumina Legum, t. VIII, f. 890-891, 925-933.

57 LPAH, SA 3702, k. 46. 
wynikały ani z konstytucji sejmowej, ani z upoważnienia Rady Nieustającej $^{58}$. Pomimo piętnowania tego typu działań, wydatkowanie ponad przyjęte regulacje nie spotykało się z negatywną oceną - komisje skarbowe uzyskiwały w sejmie absolutorium („kwit”) za swoją działalność.

\section{Próba oceny}

Do przedstawionych już zastrzeżeń trzeba dodać też to, że istnienia „budżetu” nie odnotowuje ani ówczesna nauka, ani nawet publicystyka, szeroko w czasach stanisławowskich interesująca się sprawami finansowymi państwa. Oczywiście nie mogło pojawić się samo słowo „budżet”, które dopiero w tym czasie w Wielkiej Brytanii wchodziło do użycia jako określenie planu dochodów i wydatków państwa. Co więcej, w następnych latach, po kolejnych próbach budżetowych, nie znajdziemy nawet u autorów piszących najszerzej o zagadnieniach skarbowych (H. Kołłątaj, F. Moszyński, J.F. Nax, S. Staszic) wzmianek o tej konstrukcji ani tym bardziej o jej znaczeniu czy potrzebie istnienia. Natomiast Ignacy Łobarzewski, propagujący w Polsce angielski model ustrojowy, proponował w 1789 r. jedynie, aby ustalić stałą listę cywilną, a co roku miała powstawać w sejmie tylko „Tabella expensy dla Woyska”. Takie rozwiązanie miało zresztą na celu ochronę wolności przed samowolą króla ${ }^{59}$. Co więcej, nawet Anglicy odwiedzający ówczesną Rzeczpospolitą, pisząc o jej finansach, nie zauważali istnienia budżetu ${ }^{60}$. Znaczenie aktu z $1768 \mathrm{r}$. wykreowane zostało w czasach późniejszych, począwszy zapewne od wspomnianej pracy H. Rossmana. Być może podejście takie należałoby rozpatrywać w kategorii XIX-wiecznego mitu pierwszeństwa, czyli udo-

58 W przypadku komisji koronnej były tylko takie dwa przypadki, Dyaryusz..., s. 202, 270-271.

59 [I. Łobarzewski], Testament polityczny synowi oyczyzny zostawiony z planem bezpieczney formy republikantskiego rzq̨du, Warszawa 1789, s. 128-132.

60 Zob. J. Harris, Dziennik pobytu w Polsce; J. Marshall, Podróż przez Polskę; W. Coxe, Podróż po Polsce [w:] S. Zawadzki (red.), Polska Stanisławowska w oczach cudzoziemców, t. I, Warszawa 1963. 
wadniania wcześniejszej realizacji w Polsce elementów współczesnej europejskiej rzeczywistości ${ }^{61}$.

Jak więc ocenić dzieło sejmu z 1768 r.? Choć w konstytucji słowo budżet nie padło, mamy do czynienia z jakąś formą „pra-budżetową”. Forma to ułomna, obarczona licznymi wadami, i nie chodzi tu tylko o ocenę według współczesnych standardów (pierwsze prawidłowo skonstruowane budżety pojawiły się dopiero $\mathrm{w}$ XIX $\mathrm{w}^{62}$ ), bo - jak już wskazano - problemy leżą gdzie indziej. Przede wszystkim akt z 1768 r. nie stał się podstawą gospodarki finansowej państwa, bo nigdy nie wszedł w życie. Ale nawet jako niezrealizowany projekt również nie tworzył niczego szczególnego - był tylko rachunkowym podsumowaniem odrębnie istniejących uregulowań w kwestii części wydatków i dochodów państwowych. Nie ograniczał swobody wydatkowania pieniędzy publicznych przez władze, gdyż ta - pomimo naruszeń - jako zasada od dawna w Rzeczpospolitej nie istniała. Expressis verbis wyrażono ją ustanawiając w 1764 r. administrujące dochodami i wydatkami komisje skarbowe („Expens żadnych nie ma czynić nad te, ktore Rzplita opisała (salva diminutione aut abrogatione niepotrzebnych) albo opisze") ${ }^{63}$. Czy w takim razie uprawnione jest stwierdzenie, że akt z $1768 \mathrm{r}$. jest budżetem państwa?

Wydaje się, że fakt klasyfikowania aktu z 1768 r. jako budżetu wynika tylko ze sposobu jego powstania. W wielu współczesnych definicjach budżetu zazwyczaj wśród jego elementów podkreśla się konieczność uchwalenia aktu budżetowego przez organ przedstawicielski ${ }^{64}$. Poprzez umieszczenie w definicji elementu zależnego od formy państwa czy reżimu politycznego, ze względu na specyficzny ustrój Rzeczypospolitej, ten warunek musiał być w XVIII-wiecznej Polsce spełniony. To odróżniało nasz akt od planów finansowych, powstających w tym czasie w innych krajach, a których nie określa się mianem budżetów. Brakuje tu badań prawnoporównawczych, w rozważaniach nad rozwiązaniami zaprowa-

61 Por. J. Jedlicki, Jakiej cywilizacji Polacy potrzebujq. Studia z dziejów idei i wyobraźni XIX wieku, Warszawa 2002, s. 70-71.

R. Rybarski, Skarbowość...., s. 48; tenże, Nauka..., s. 64.

Volumina Legum, t. VII, f. 31, 158.

Zob. np. A. Borodo, Polskie prawo finansowe. Zarys ogólny, Toruń 2014, s. 37. 
dzonymi w Rzeczypospolitej całkowicie pomija się rozwój instytucji prawno-finansowych. Choć powstanie budżetu wiązało się na zachodzie Europy z rozwojem form parlamentarnych, to argument, iż bez sankcji parlamentarnej nie ma budżetu, powodowałby eliminację tej instytucji we wszystkich państwach niedemokratycznych ${ }^{65}$.

Co więcej, sejm zwany repninowskim pracujący w latach 17671768, odbywany w asyście wojsk rosyjskich, w założeniach nie był reformatorski, a wręcz przeciwnie - jego celem było zahamowanie zbyt daleko idących zmian wprowadzonych w pierwszych latach panowania Stanisława Augusta i spetryfikowanie istniejącego ustroju. W naszym przypadku akt z 1768 r. nie powstał wskutek odebrania monarsze prawa do dysponowania pieniędzmi państwowymi (tj. ze skarbu publicznego), bo ten od dawna takich kompetencji nie posiadał. Podróżujący po ówczesnej Polsce Anglik James Harris nie tylko nie nazwał regulacji sejmowej budżetem, za to przedstawił jej odmienne znaczenie - chodziło o powiązanie dochodów z wydatkami tak, aby niemożliwe było zebranie jakichkolwiek nadwyżek i tym samym sprawienie, aby Rzeczpospolita była „groźną dla sąsiadów”66. Potwierdzenie zasadności tej opinii można znaleźć jeszcze w 1791 r., gdy po uwolnieniu spod rosyjskiej kurateli, na tygodnie przed uchwaleniem Konstytucji 3 maja, padł 22 marca na sali sejmowej głos związanego z obozem reform posła wileńskiego Tadeusza Korsaka, postaci unieśmiertelnionej na pierwszych stronach „Pana Tade-

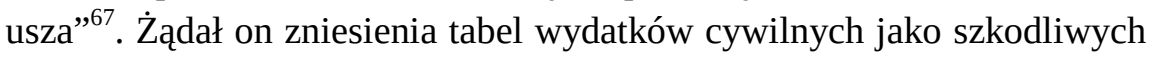
i uchwalonych „przemysłem zagraniczney Inflyencyi na sciesnienie Skarbu publicznego i niedopuszczenia wzrostu siłom Kraiowym”68.

65 Pomijając kwestie ustrojowe, za istotne uznać należy tylko, by był przyjęty „w sposób prawem przepisany”, I. Czuma, Budżet..., s. 75.

66 J. Harris, Dziennik pobytu..., s. 298.

67 „Dalej Jasiński, młodzian piękny i posępny Obok Korsak towarzysz jego nieodstępny Stoją na szańcach Pragi, na stosach Moskali

Siekąc wrogów, a Praga już się wokół pali” (A. Mickiewicz, Pan Tadeusz, ks. I, w. 65-68).

68 Zapisano, że chodzi o tabele uchwalone na sejmach w latach 1768, 1776 i 1778, co w ostatnim przypadku jest zapewne omyłką, bo sejm w 1778 r. nie zajmował się tabe- 
Na zasadność klasyfikowania aktu z 1768 r. jako budżetu nie pozwalają też zasady budżetowe. Choć nie mają one znaczenia ponadczasowego i ponadprzestrzennego, a ich treść ulega zamianom wraz ze zmianami funkcji państwa i jego budżetu ${ }^{69}$, to jednak to, co uchwalił sejm, bardzo dalekie było od spełnienia którejkolwiek z nich. W dodatku akt z 1768 r. nie miał żadnego praktycznego znaczenia - nie tylko nie został wykonany, ale dokonywano wydatków, jakby w ogóle nie istniał. Mógł więc jedynie unaoczniać wysokość potrzeb finansowych państwa, ale nie mógł uzdrowić stosunków skarbowych. Stanowić też mógł wzorzec na przyszłość, choć trudno uwierzyć, by umożliwiał eliminowanie popełnionych błędów konstrukcyjnych przy układania kolejnych projektów ${ }^{70}$, bo te można dostrzec dopiero w praktyce realizacji, do której przecież nie doszło.

\section{Wnioski}

Problemu pierwszego polskiego „budżetu” nie można uznać za wyczerpany. Przede wszystkim nie są do końca jasne inspiracje i przebieg prac nad samą konstytucją z 1768 r. Być może przyszłe badania nad życiem politycznym i parlamentaryzmem epoki pozwolą na rozjaśnienie tych kwestii. Jednak już dziś wydaje się, że należy ostrożniej posługiwać się pojęciem „budżet” względem regulacji z 1768 r. Współczesne definicje podkreślają dyrektywność, roczność czy planowość budżetu ${ }^{71}$, a jak wynika z przeprowadzonej analizy, akt z 1768 r. mógł spełniać ledwie ostatni warunek. Ówczesny ustrój i struktura państwa, staropolska nieuporządkowana skarbowość, nie pozwalały na zbudowanie budżetu.

Sejm w 1768 r. uchwalił konstytucję, którą - posługując się współczesną terminologią - można byłoby spróbować nazwać ustawą budżeto-

lami wydatków, zrobił to natomiast sejm w 1775 r., Archiwum Główne Akt Dawnych w Warszawie (AGAD), Archiwum Sejmu Czteroletniego, 17, k. 577v, 578.

69 Zob. J. Lubowicki, Budżet i zasady budżetowe, „Państwo i Prawo” 1964, nr 8-9, s. 210-211.

70 M. Drozdowski, Podstawy..., s. 58-59.

71 A. Drwiłło (red.), Podstawy finansów...,, s. 324; B. Brzeziński, A. Olesińska (red.), Prawo finansów..., s. 87-88. 
wą. Moglibyśmy tak zrobić, gdyby nie to, że jej zawartość nie daje się nazwać budżetem, a jest co najwyżej jego niedoskonałym i w dodatku niezrealizowanym projektem. Sam budżet bowiem w 1768 r. nie powstał. Sformułowanie R. Rybarskiego, iż sejm „uchwalił coś w rodzaju budżetu"72, chyba najtrafniej oddaje rzeczywistą wartość ówczesnego dorobku Rzeczypospolitej w dziedzinie budżetowej.

\section{Bibliografia:}

Bardach J., Leśnodorski B., Pietrzak M., Historia ustroju i prawa polskiego, LexisNexis, Warszawa 2009.

Bielak J., Ogólna charakterystyka ustawy budżetowej z roku 1768, „Finanse” 1968, nr 1, s. 14-23.

Borodo A., Budżet państwa a zasady budżetowe [w:] Nauka finansów publicznych i prawa finansowego w Polsce. Dorobek i kierunki rozwoju. Księga jubileuszowa profesor Alicji Pomorskiej, Wydawnictwo Uniwersytetu Marii Curie-Skłodowskiej, Lublin 2008, s. 167-173.

Borodo A., Polskie prawo finansowe. Zarys ogólny, Towarzystwo Naukowe Organizacji i Kierownictwa „Dom Organizatora”, Toruń 2014.

Brzeziński B., Olesińska A. (red.), Prawo finansów publicznych, Towarzystwo Naukowe Organizacji i Kierownictwa „Dom Organizatora”, Toruń 2017.

Chojna-Duch E., Podstawy finansów publicznych i prawa finansowego, LexisNexis, Warszawa 2012.

Ciesielski T., Armia koronna w czasach Augusta III, Wydawnictwo DiG, Warszawa 2009.

Coxe W., Podróż po Polsce, [w:] S. Zawadzki (red.), Polska Stanisławowska w oczach cudzoziemców, t. I, Państwowy Instytut Wydawniczy, Warszawa 1963.

Czuma I., Budżet, [w:] Z. Cybichowski (red.), Encyklopedia podręczna prawa publicznego, t. I, „Biblioteka Polska”, Warszawa s.a., s. 75-82.

Drozdowski M., Działalność budżetowa sejmu Rzeczpospolitej w czasach saskich, „Roczniki Dziejów Społecznych i Gospodarczych” 1977, t. 38, s. 119-144.

72 R. Rybarski, Skarbowość..., s. 30. 
Drozdowski M., Poczq̨tki prawa budżetowego w Rzeczypospolitej w czasach Stanisława Augusta, „Czasopismo Prawno-Historyczne”, 1978, t. 30, z. 1, s. $123-144$.

Drozdowski M., Podstawy finansowe działalności państwowej w Polsce 17641793. Działalność budżetowa Sejmu Rzeczypospolitej w czasach panowania Stanisława Augusta Poniatowskiego, Państwowe Wydawnictwo Naukowe, Warszawa-Poznań 1975.

Drwiłło A. (red.), Podstawy finansów i prawa finansowego, Wolters Kluwer, Warszawa 2014.

Gajl N., Budżet a skarb państwa, Państwowe Wydawnictwo Ekonomiczne, Warszawa 1974.

Gajl N., Gospodarka budżetowa w świetle prawa porównawczego, Wydawnictwo Naukowe PWN, Warszawa 1993.

Gaudemet P.M., Molinier J., Finanse publiczne, Polskie Wydawnictwo Ekonomiczne, Warszawa 2000.

Grajewski H., Granice czasowe mocy obowiq̨zujq̨cej norm dawnego prawa polskiego, Łódzkie Towarzystwo Naukowe, Łódź 1970.

Harris J., Dziennik pobytu w Polsce, [w:] S. Zawadzki (red.), Polska Stanisławowska w oczach cudzoziemców, t. I, Państwowy Instytut Wydawniczy, Warszawa 1963.

Jedlicki J., Jakiej cywilizacji Polacy potrzebujq. Studia z dziejów idei i wyobraźni XIX wieku, Wydawnictwo W.A.B., Warszawa 2002.

Konopczyński W., Konfederacja barska. Przebieg, tajemne cele i jawne skutki, T. 2, Wydawnictwo Zysk i s-ka, [Poznań 2017].

Korzon T., Wewnętrzne dzieje Polski za Stanisława Augusta (1764-1794), t. III, L. Zwoliński i s-ka/Teodor Paprocki i s-ka, Warszawa-Kraków 1897.

Kosikowski C., Budżet państwa jako kategoria historyczna, ekonomiczna i prawna, [w:] E. Ruśkowski (red.) System prawa finansowego, T. 2 Prawo finansowe sektora finansów publicznych, Wolters Kluwer, Warszawa 2010, s. 179-230.

Kutrzeba S., Historia ustroju Polski. Korona, Poznańskie Towarzystwo Przyjaciół Nauk, Poznań 2001.

Lubowicki J., Budżet i zasady budżetowe, „Państwo i Prawo” 1964, nr 8-9, s. 206-217.

[Łobarzewski I.], Testament polityczny synowi oyczyzny zostawiony z planem bezpieczney formy republikantskiego rzqdu, Warszawa 1789. 
Łojek J., Mecenat kulturalny Stanisława Augusta: państwowy czy prywatny? [w:] tenże, Wokół sporów i polemik, Wydawnictwo Lubelskie, Lublin 1991, s. $158-163$.

Maciejewski T., Historia ustroju i prawa sq̨dowego Polski, Wydawnictwo C.H. Beck, Warszawa 2011.

Marshall J., Podróż przez Polskę [w:] S. Zawadzki (red.), Polska Stanisławowska w oczach cudzoziemców, t. I, Państwowy Instytut Wydawniczy, Warszawa 1963.

Mastalski R., Fojcik-Mastalska E. (red.), Prawo finansowe, Wolters Kluwer, Warszawa 2013.

Nycz M., Geneza reform skarbowych Sejmu Niemego. Studium z dziejów skarbowo-wojskowych z lat 1697-1717, Poznańskie Towarzystwo Przyjaciół Nauk, Poznań 1938.

Pałucki W., Drogi i bezdroża skarbowości polskiej XVI i pierwszej połowy XVII wieku, Zakład Narodowy im. Ossolińskich, Wrocław 1974.

Pawiński A., Skarbowość Polski i jej dzieje za Stefana Batorego, Gebethner i Wolff, Warszawa 1881.

[Pawlikowski J.], Myśli polityczne dla Polski, Warszawa 1789.

Pietrzak M., Gospodarka budżetowa w Polsce w latach 1768-1792. Między tradycjq a nowoczesnością, „Przegląd Sejmowy” 1999, nr 5, s. 9-19.

Pilarczyk P.M., Poczq̨tki instytucji budżetu państwa w Polsce, Wydawnictwo Nauka i Innowacje, Poznań 2014.

Rossman H., Rys historyczny budżetu w Polsce, „Ekonomista” 1865, kwartał 4, s. 13-23, 81-96; 1866, s. 1-21; 1868, II półrocze, s. 217-229.

Rostworowski E., Legendy i fakty XVIII w., Państwowe Wydawnictwo Naukowe, Warszawa 1963.

Rybarski R., Nauka skarbowości, Wolters Kluwer, Warszawa 2015.

Rybarski R., Skarbowość Polski w dobie rozbiorów, Polska Akademia Umiejętności, Kraków 1937.

Stahl Z., Istota budżetu na tle rozwoju historycznego i współczesnych tendencyj konstytucyjnych, Towarzystwo Naukowe, Lwów 1934.

Szcząska Z., Odpowiedzialność rzq̨du w Polsce w latach 1775-1792, „Czasopismo Prawno-Historyczne” 1975, t. 27, z. 1, s. 55-107.

Weralski M., Budżet państwowy, [w:] M. Weralski (red.), System instytucji prawno-finansowych PRL, T. 2 Instytucje budżetowe, Zakład Narodowy im. Ossolińskich, Wrocław 1982. 